\title{
УДК 616.71-007.15
}

\section{THE DEPENDANCE OF RESISTANCE IN RESPIRATORY INFECTIONS, VITAMIN D DEFICIENCY AND ACADEMIC ACHIEVEMENT ON PHYSICAL ACTIVITY OF STUDENTS}

\author{
Abramova N. \\ C.M.S., Associate professor. \\ ORCID: 0000-0001-5621-1294 \\ Syed Mohammed Noushad \\ Bukovinian State Medical University, Chernivtsi, Teatralna sq, 2,58002
}

\begin{abstract}
.
Introduction: Problems arising in the process of educational activities related to physical and mental health, adaptation of students to the conditions of study, improving efficiency, drawing up a proper schedule taking into account the workload, research activities, are of particular importance.

Materials and methods: 65 students were enrolled into the study to examine the relationship between physical activity and academic achievement.

Results: GPA correlated positively with hours of studying and hours of physical activity, vitamin $D$ and negatively with BMI, frequency of acute respiratory viral infections of the upper respiratory tract.

Conclusion: It has been revealed that physical activity had a positive effect on learning outcomes and resistance to upper respiratory tract infections. Sedentary lifestyle and longer use of social media, contributed to an increase in body mass index and vitamin D deficiency, frequency of acute respiratory viral infections of the upper respiratory tract.
\end{abstract}

Key words: physical activity, vitamin D, sedentary lifestyle, academic outcomes.

\section{Introduction.}

It is known that physical activity has an impact on cognitive skills such as concentration and attention, and it also enhances classroom attitudes and behaviours, all of which are important components of improved academic performance.

Some studies have reported the development of vitamin D deficiency in people with intellectual disabilities and in people with frequent acute respiratory tract infections $[2,4]$.

Recent studies reported that the number of mental and intellectual activities of the student increases, physical activity decreases, the alternation of physical and mental loads is reduced. As a result, fatigue accumulates faster, the ability to concentrate and switch attention from one activity to another decreases, the overall efficiency decreases [1,3].

Besides physical activity is one of the easiest and most affordable ways to maintain a healthy immune system. Scientists have long discovered a link between regular exercise and a reduction in the number of diseases.

Average adult suffers from colds about two and a half times a year. Various viruses affect the human body on a regular basis, but some people are more resistant.

People who start running regularly stop getting sick often. Researchers say that just five regular workouts a week reduces the risk of catching a cold by 43 to 46 percent.

Scientists suggest that regular moderate physical activity stimulates the immune 
system, encouraging it to increase the production of macrophages. These cells attack viruses and bacteria that enter the body $[5,6,7]$.

Thus, a decrease in physical activity of students can lead to a decrease in the effectiveness of training both by reducing the ability to concentrate and by increasing the frequency of seasonal acute infectious diseases of the respiratory tract, accompanied by weakness, missing workshops, seminars and lectures.

The aim of the study: was to examine the relationship between vitamin D deficiency, physical activity, frequency of upper respiratory tract infection and academic achievement

\section{Materials and methods:}

65 students (36 females, 29- males) aged 22.1 \pm 2.3 years were enrolled into the study between September-October 2021 and provided written consent to use their data.

Protocol of examination included following data:

Body Composition - Height, weight, Body Mass Index (BMI), percentage of subcutaneous and visceral fat using bioimpedance meter weighing scale (OMRON BF 511) were estimated.

Demographics - Students self-reported their current academic year, age, sex.

The content of visceral fat was considered to be elevated in the range of $6-12 \%$, more than $13 \%$ - very high. The normal fat content in the body in this age group should be in the range of 20-28\%,29\% and above - is considered high.

All individuals underwent a single serum $25(\mathrm{OH}) \mathrm{D}$ study. Vitamin D insufficiency was diagnosed at a level of $25(\mathrm{OH}) \mathrm{D}$ below $50 \mathrm{nmol} / 1$ or $20 \mathrm{ng} / \mathrm{ml}$. In addition, severe vitamin D deficiency was recorded at a level of $25(\mathrm{OH}) \mathrm{D}$ below $25 \mathrm{nmol} / 1$ (10 ng / ml). Vitamin D deficiency was diagnosed at 50-75 nmol / 1 (20$30 \mathrm{ng} / \mathrm{ml})$. To determine the level

$25(\mathrm{OH}) \mathrm{D}$ in the blood serum used electrochemiluminescent method. The study was performed using the Elecsys 2010 device (Roche Diagnostics, Germany) using cobas test systems.

Behavioral Outcomes - minutes per week of moderate and vigorous physical activity were used in analyses - dichotomized as less than/greater than 90 minutes/week, based on the median reported time. Students were asked to report number of hours/days spent sitting or reclining on a typical weekday to examine sedentary behavior. Participants also reported how many hours per day they spent using social media using a continuous scale of 0-24 hours. The distribution for social media was examined and the median was 2 hours per day, then social media use was dichotomized as less than or greater than 2 hours per day.

Resistance to infection: The distribution for frequency of acute respiratory viral infections of the upper respiratory tract was examined and median was 3 per year then was dichotomized as 3 and more per year.

Academic Factors - Individuals reported their current grade point average (GPA) using a continuous scale. The distribution was then examined and the median was 3.2. GPA was then dichotomized into less than/equal to or greater than 3.2 (all values rounded to the nearest tenth). Participants also indicated how many hours per day they spent studying and doing academic work - dichotomized as less than/greater 
than 2 hours, based on the median reported time.

Basic descriptive statistics described the sample. Pearson correlations examined the relationships between the fitness, behavioral and academic outcomes. Significance levels were set at $\mathrm{p}<0.05$.

\section{Results:}

The average BMI of the subjects was $28.4 \pm 6.8 \mathrm{~kg} / \mathrm{m} 2$, visceral fat $7.4 \pm 3.2 \%$, the total fat content in the body was $29 \pm 5.3 \%$.

Vitamin D insufficiency was found in $86.1 \%$ of students, and vitamin D deficiency in $6.1 \%$.

Physical activity more than 90 minutes/week was reported by $52 \%$ of students. $65 \%$ of students reported studying more than 2 hours/day, $71 \%$ reported using more than two hours of social media per day, frequency of acute respiratory viral infections of the upper respiratory tract more than 3 per year $-68 \%$ and $58 \%$ of the sample had a GPA equal to or greater than a 3.3.

Hours of studying was positively associated with BMI $(\mathrm{r}=0.468, \mathrm{p}<0.05)$, percentage of visceral $(\mathrm{r}=0.514, \mathrm{p}<0.05)$, and subcutaneous fat $(\mathrm{r}=0.562, \mathrm{p}<0.05)$, and negatively associated with the level of vitamin $\mathrm{D}(\mathrm{r}=-0.562, \mathrm{p}<0.05)$, and physical activity $(\mathrm{r}=-0.433, \mathrm{p}<0.05)$.

Hours of social media using associated positively with BMI $(\mathrm{r}=0.474, \mathrm{p}<0.05)$ percentage of visceral $(\mathrm{r}=0.629, \mathrm{p}<0.05)$, and subcutaneous fat $(\mathrm{r}=0.684, \mathrm{p}<0.05)$, and frequency of acute respiratory viral infections of the upper respiratory tract more than 3 per year $(r=0.373, p<0.05)$ and negatively associated with the level of vitamin $D$ $(\mathrm{r}=-0.596, \mathrm{p}<0.05)$, and physical activity $(\mathrm{r}=-0.511, \mathrm{p}<0.05)$.

GPA correlated positively with vitamin $\mathrm{D}$ level $(\mathrm{r}=0.443, \mathrm{p}<0.05)$, hours of studying $(\mathrm{r}=0.462, \mathrm{p}<0.05)$ and hours of physical activity $(\mathrm{r}=0.427, \mathrm{p}<0.05)$, and negatively - percentage of visceral $(\mathrm{r}=-0.459, \mathrm{p}<0.05)$, and subcutaneous fat $(\mathrm{r}=-$ $0.532, \mathrm{p}<0.05$ ), with frequency of acute respiratory viral infections of the upper respiratory tract $(\mathrm{r}=0.348, \mathrm{p}<0.05)$.

The level of vitamin D in serum correlated negatively with frequency of acute respiratory viral infections of the upper respiratory tract $(\mathrm{r}=-0.714, \mathrm{p}<0.05)$.

\section{Discussion:}

Vitamin D deficiency in students who had poorer academic achievements in the study group is likely to be associated with a sedentary lifestyle. It is also known that vitamin $\mathrm{D}$ is fat-soluble and people who have high body fat need higher doses of vitamin D for the optimal body in need. Meanwhile, students who performed better were physically active, including exercising outdoors, and spent less than 30 minutes on social media.

Observational studies report consistent independent associations between low serum concentrations of 25 -hydroxyvitamin $\mathrm{D}$ (the major circulating vitamin D metabolite) and susceptibility to acute respiratory tract infection. 25-hydroxyvitamin $\mathrm{D}$ supports induction of antimicrobial peptides in response to both viral and bacterial stimuli, suggesting a potential mechanism by which vitamin $\mathrm{D}$ inducible protection against respiratory pathogens might be mediated [4].

Thus, it is necessary to prescribe colecalciferol in order to prevent and correct its deficiency during the school year. 


\section{Conclusions:}

1. Physical activity had a positive effect on learning outcomes and resistance to upper respiratory tract infections.

2. Sedentary lifestyle and longer use of social media, contributed to an increase in body mass index and frequency of acute respiratory viral infections of the upper respiratory tract, and vitamin D deficiency.

3. It is necessary to prescribe cholecalciferol in order to prevent and correct its deficiency during the school year.

\section{References:}

1. Сбитнева О.А. (2017) Воздействие учебного процесса на организм студентов // Universum: психология и образование: электрон. научн. журн. 2017. № 1 (43). URL: https://7universum.com/ru/psy/archive/item/5432

2. Catherine Walton, Andrew Isaac, Mike Kerr (2019) Prevalence of vitamin D deficiency in people with learning disability: A systematic review. British journal of learning disability. 47 (4), 279-288. https://doi.org/10.1111/bld.12285

3. Jesse Calestine, Melissa Bopp, Christopher M. Bopp, Zack Papalia (2017). College Student Work Habits are Related to Physical Activity and Fitness. International Journal of Exercise Science 10 (7), P. 1009-1017. Available at: https://digitalcommons.wku.edu/ijes/vol10/iss 7/8

4. Martineau, A. R., Jolliffe, D. A., Hooper, R. L., Greenberg, L., Aloia, J. F., Bergman, P., Dubnov-Raz, G., Esposito, S., Ganmaa, D., Ginde, A. A., Goodall, E. C., Grant, C. C., Griffiths, C. J., Janssens, W., Laaksi, I., Manaseki-Holland, S., Mauger, D., Murdoch, D. R., Neale, R., Rees, J. R., ... Camargo, C. A., Jr (2017). Vitamin D supplementation to prevent acute respiratory tract infections: systematic review and meta-analysis of individual participant data. BMJ (Clinical research ed.), 356, i6583. https://doi.org/10.1136/bmj.i6583

5. Skiera B, Hinz O, Spann M. (2015) Social Media and Academic Performance: Does the Intensity of Facebook Activity Relate to Good Grades? SBR January:54-72.

6. Van Dyck D., De Bourdeaudhuij I., Deliens T., Deforche B. (2015) Can changes in psychosocial factors and residency explain the decrease in physical activity during the transition from high school to college or university? Int J Behav Med 22(2):178-186.

7. Weyh Christopher, Krüger Karsten, Strasser Barbara (2020). "Physical Activity and Diet Shape the Immune System during Aging." Nutrients 12, no. 3, 622. https://doi.org/10.3390/nu12030622 